\title{
Health and Pension Insurance of Seafarers in the Republic of Croatia
}

\author{
Blanka Ivančić-Kačer
}

In practice issues with no clear-cut answers are raised almost on a daily basis. The author deals with some very topical issues relating to pension and health insurance in the Republic of Croatia - the issues of accelerated years of pensionable service for seafarers, pension bonuses and the very meaning of the term seafarer.

\section{KEY WORDS}

$\sim$ Pension insurance

$\sim$ Health insurance

$\sim$ Accelerated years of pensionable service for seafarers

$\sim$ Seafarer pension bonus

$\sim$ Seafarers in the Republic of Croatia

University of Split, Faculty of Maritime Studies, Zrinsko-Frankopanska 38, 21000 Split, Croatia

e-mail: bkacer@pfst.hr

\section{INTRODUCTION}

Throughout the world (i.e. this is a worldwide, global trend, at least in the so called developed societies) our time is characterized by great social sensitivity and conflict (often dramatic) between the substantially or completely opposing attitudes on whether we are doing everything we can in this area or far less than that, as well as where the limits of the possible objectively lie. Within the framework of the general concept of social issues, health and pension insurance certainly have a special place. That makes the issues of health and pension insurance of seafarers more than worthy of scientific analysis and study, the goal being first to clearly present the individual issues and then to analyse them de lege lata in Croatian law, including the de lege ferenda proposals. We wish to bring into the foreground two possible solutions to the present legal issues - the first and the best (because it best fulfils the legal safety and rule of law requirements) is the appropriate modification of the normative framework (either by a new act or amendment of the present act), the second ( $a$ necessary evil of sorts or a temporary solution, e.g. because the reaction time of the legislator is too long) is the achievement of change through the interpretation process, within which, in accordance with the best standards applicable in the acquis communautaire, the target or teleological interpretation have a special place. In so doing, at least in principle, ratio legis is that the seafarer (partly because of the seafarer, but largely also to protect the wider interests of the entire community, because the unsatisfactory position of seafarers is causing ever decreasing numbers of people to work in this branch of the economy, which is surely one of the strategic branches). In spite of being a branch of strategic interest, it is simultaneously a branch in which there exists an immense disproportion between the declaratively very strong support in every sense and the actual measures taken, 
including the appropriate legal framework, which fall far behind what could be called a real and appropriate support. The list of possible examples of legislative shortcomings is long, as clearly manifested in the fact that the Croatian positive legislation unfortunately does not even have the legal definition of the term seafarer, although the term is used (Šimac, 1999; Primorac, 2008), and there is a very real possibility of discrepancy with the Maritime Labour Convention (Maritime Labour Convention, 2012), which does not recognize the duality of the terms seafarer and crew member.

\section{LEGAL SOURCES}

The Constitution of the Republic of Croatia (Constitution of the Republic of Croatia, 1990; Constitution of the Republic of Croatia, 1997; Constitution of the Republic of Croatia, 1998; Constitution of the Republic of Croatia, 2000; Constitution of the Republic of Croatia, 2001; Constitution of the Republic of Croatia, 2001a; Constitution of the Republic of Croatia, 2001b; Constitution of the Republic of Croatia, 2010) is the main legal source for this subject matter, as well as any other subject matter relating to the Croatian legal system. The Constitution only contains general provisions, and for a general provision to be effective, it must be further elaborated by legal acts and sublegal regulations. We will list the provisions of the Constitution which served as the basis for the adoption of the acts which further elaborated these principles, making it possible for a part (content-wise) of the declaration to cross over to the stage of something operationalized and efficient, allowing the application of the general constitutional provisions to everyday life.

Given the topic of this paper, the key legal sources are the regulations governing the pension and health insurance of seafarers and, of course, the Maritime Code (Maritime code, 2004; Maritime code, 2007; Maritime code, 2008; Maritime code, 2011), defining a number of key terms like, e.g. ship and boat, but unfortunately not the term seafarer. Since the aforementioned regulations are special regulations which, as a rule, only partially deviate from the general solutions, the legal sources also include the so called empowering acts, i.e. Pension Insurance Act (Pension Insurance Act, 1998; Pension Insurance Act, 2000; Pension Insurance Act, 2001; Pension Insurance Act, 2001a; Pension Insurance Act, 2002; Pension Insurance Act, 2003; Pension Insurance Act, 2004; Pension Insurance Act, 2004a; Pension Insurance Act, 2005; Pension Insurance Act, 2007; Pension Insurance Act, 2007a; Pension Insurance Act, 2008; Pension Insurance Act, 2010; Pension Insurance Act, 2010a; Pension Insurance Act, 2010b; Pension Insurance Act, 2011; Pension Insurance Act, 2011a), Act on Insurance with Increased Duration (Act on Insurance with Increased Duration, 1999; Act on Insurance with Increased Duration, 2007; Act on Insurance with Increased Duration, 2008), Mandatory Health Insurance
Act (Mandatory Health Insurance Act, 2008), Labour Act (Labour Act, 2009; Labour Act, 2011) and Act on the Addition to Pensions Realised under the Pension Insurance Act (Act on the Addition to Pensions, 2007; Act on the Addition to Pensions, 2011).

Of course, every other regulation, of any level, in any way dealing with this problem area should also be considered as such. International agreements, which in accordance with Article 141 of the Constitution ${ }^{(1)}$ have legal force above the law, are also legal sources, under three conditions. First, that they have been published, second that they have been ratified and third, that they entered into force and effect (the third point is important because it often takes months, even years for the conditions for entry into force of international agreements to be met, most frequently the number of signatory countries).

Although the Republic of Croatia is as yet not a member of the EU, EU guidelines and other documents constituting the community acquis or acquis communautaire have a vital role.

The informal legal sources are the legal science and judicial practice as legal sources suigeneris. Judicial practice acts through the power of argument, but also through the argument of power, because higher courts have the authority to impose their legal opinions on lower courts, while the legal science acts merely through the power of argument, due to the non-existence of obligation to accept and apply it.

\section{AN OVERVIEW OF POSITIVE LEGISLATION DE LEGE LATA}

As previously mentioned, until the normative framework is adequately modified by the legislator, the resolution of the present legal issues can be sought in the interpretation process which is often complex and requires both knowledge and skill. Interpretation is "...a mental activity revealing the possible meanings of legal provisions and in them the hypotheses, searches, the identification of the offence and sanction, and deciding which of the possible solutions is the best" (Visković, 2001). Since legal norm is an assembly of words endowed with certain meaning, language interpretation comes first. A schoolbook example is the pun: "You will go return not die." (Kačer, 2011) It is followed by logical interpretation connoting the application of special principles of legal logic-argumentum a contrario, argumentum a minori ad maius, argumentum a maiori ad minus...There is also the historical method, expanded, narrowed down ... However, according to the rules applicable in

1 International agreements concluded and ratified in accordance with the Constitution, which have been published and are in force are a part of the internal legal order of the Republic of Croatia and are above the law by their legal force. Their provisions may be amended or revoked only under the conditions and in the manner therein established or in keeping with the general rules of international law. 
acquis communautaire, targeted or teleological interpretation has a special place. It examines the role of the legal norm in the society, arriving at the conclusion that its true meaning in a particular legal relation is the one best reflecting the prevailing social goals (Kačer, 2011). Since this method is decisive and final in the interpretation process, we used it to establish the actual meaning of the legal norms from this problem area.

The seafarer health and pension insurance legislation is notoriously special in comparison with that legally regulating these areas for everyone except those to whom special regulations apply. That means that we must first consider the general norms, establish whether there are any deviations in special regulations and if there are, which deviations have precedence if the principle of lex specialis derogat legi generali is applied. Due to the nature of things, the definition of the seafarer is the key information, i.e. the legal provision starting from which we must establish to whom the provisions governing the health and pension insurance of seafarers apply. Unfortunately, since such definition is absent from the Croatian positive legislation, we must make do with what we have, and that is the term "crew member", with a note that these two terms are not synonymous - the term seafarer is broader, because every crew member is simultaneously a seafarer, but a seafarer need not necessarily be a crew member and can also be an unemployed person of marine vocation (Primorac, 2008). We will now quote key parts of the law for what we are dealing with in this paper, noting that due to the limited space we were forced to limit ourselves only to the most relevant, with the suggestion that the readers, use the provided data(2) to gain an insight into the integral legal text.

\section{ACT ON INSURANCE WITH INCREASED DURATION (3), OG 71/99}

Article 4. paragraph 2, section XV IN TRANSPORT

2. Workplaces in marine transport

1) Workplaces of on-board personnel on tankers transporting liquid fuel during unrestricted navigation and marine cabotage.

Every 12 months spent on such workplaces shall be counted as 15 months of pensionable service.

2) Workplaces of on-board personnel, with the exception of personnel under 1), on ships navigating the areas of

2 We are primarily referring to the website of the publisher of the Official Gazette of the Republic of Croatia - www.narodne-novine.nn.hr at which all regulations have been published in an integral form, and which is freely accessible to anyone and unrestricted (not even restricted by payment).

3 The quoted provision was put out of legal force by the latest amendment of the Maritime Code, by a nomotechnically best way, explicitly. unrestricted navigation and marine cabotage $80 \%$ of the year. Every 12 months spent on such workplaces shall be counted as 14 months of pensionable service.

The fact that a virtual little war was waged between the representatives of seafarers (primarily their unions) for years, inter alia over the so called accelerated years of pensionable service or insurance with increased duration, leaves a very bad impression about the legal safety and rule of law. Someone obviously didn't do their work well, because the provision of the Act on Insurance with Increased Duration, dating back to the now distant 1999, was never put out of force, providing that the fact that even at that time this issue was not applicable to all seafarers, but merely to those paying their own contributions, is not decisive.

MARITIME CODE, OG 181/04.

Chapter VIII.

THE SHIP'S CREW

1. General provisions

Article 125.

(1) Ship's crew shall consist of commander and other persons embarked for the purposes of performance of works on board and entered into the crew list.

(2) When embarking on the ship in international navigation crew member shall have a concluded written work contract.

Article 128

(1) A crew member of a ship in international navigation shall be liable for employment income tax payment based on earnings from work aboard a ship in international navigation and payment of contributions for all compulsory insurances.

(2) The registration and cancellation of the compulsory pension scheme and the health insurance of a crew member of a ship in international navigation shall be made by the employer, i.e. the ship owner.

\section{Article 129}

(1) The salary a crew member would earn for the same or similar jobs on a ship in national navigation, established by the minster by a special regulation, shall serve as a monthly basis for the calculation of contributions from Article 128, paragraph 1 of this Code.

(2) The amount of the sailing bonus of a crew member of a ship in international navigation, not included in the taxable part of income, shall be established by the minister competent for financial issues.

(3) The employer shall not be liable for the payment of taxes, surtaxes, contributions and other payments on disbursements to a crew member of a ship in international navigation. 
The provisions defining the crew member are very clear, however, a written work contract is proscribed only for international navigation. We are not convinced that this is in the best interest of seafarers, especially in view of the general provisions of the Law of Obligations stipulating that the lack of form can still convalidate. It is likewise relevant that it is proscribed that, although a seafarer in international navigation is liable for the payment of contributions for all compulsory insurance schemes, it is the employer who is liable for the registration and cancellation of the pension and health insurance. That means and must mean that the employer is also liable if it fails to make the registration and cancellation. It would also be a good idea if a seafarer could, if he/she wishes and if the employer fails to do so, could make the registration/cancellation on his/her own.

\section{Official Gazette 76/07}

Article 13.

Article 128 shall be amended and read as follows:

(1) A crew member in international navigation, regardless of the ship's nationality, who has a permanent residence or a temporary residence in the Republic of Croatia (resident), shall be liable to employment income tax payment based on earnings from work aboard a ship in international navigation unless he sailed for 183 or more days in the year for which the income tax payment liability is established. The period of 183 days may be discontinuous.

(6) The contributions paid in the course of a tax period for compulsory insurance schemes of the crew member referred to in Paragraph 1 herein shall also be accepted as tax deduction expenses in accordance with provisions of Article 129 of this Code.

(7) The sum of the sailing bonus amount calculated in accordance with Paragraph 5 and the amounts of contributions paid in accordance with Paragraph 6 herein may not exceed the total amount of earnings from work aboard a ship in international navigation as specified in Paragraph 4 herein. The balance between the earnings reduced by the sailing bonus and the expenses for contributions shall be the income from employment which represents the basis to establish the income tax liability or the non-existence of such liability depending on the number of navigation days pursuant to Paragraph 1 herein.

\section{Article 14}

Article 129. shall be amended and read as follows:

(1) A crew member in international navigation, regardless of the ship's nationality, shall be an insured person with a compulsory pension scheme in the Republic of Croatia if he or she has a permanent residence or a temporary residence (resident) in the Republic of Croatia and a compulsory medical insurance, as well as occupational safety and health insurance if he or she has a permanent residence or an approved permanent sojourn in the Republic of Croatia, unless otherwise regulated by an interstate social insurance contract.

(2) The registration of the compulsory pension scheme and the compulsory health insurance of the crew member referred to in Paragraph 1 herein, whose employer is a domestic corporate entity, and the cancellation thereof shall be made by the employer.

(3) The registration of the compulsory pension scheme and the compulsory health insurance of the crew member referred to in Paragraph 1 herein, whose employer is a foreign corporate entity, and the cancellation thereof shall be made by a competent port authority.

(4) The port authority shall not make the registration referred to in Paragraph 3 herein if the crew member referred to in Paragraph 1 herein supplies evidence to the port authority that he or she has a compulsory insurance provided by a foreign social insurance authority of the state with which the Republic of Croatia has concluded a social insurance contract.

(5) The agency in charge of finding employment for seamen referred to in Article 125a, Paragraph 2 of this Code, as well as the seamen who have found employment on their own with a foreign employer or who have been employed by a foreign employer through the Croatian Employment Bureau shall be liable to submit to the competent port authority all the data that are needed for the registration of the compulsory pension scheme and the compulsory health insurance, as well as the cancellation thereof.

(6) The day of boarding a ship shall be deemed the beginning of insurance of the crew member referred to in Paragraph 1 herein, while the day when he or she has been discharged from a ship shall be deemed the termination of insurance as evidenced by the seaman's book.

(8) The crew member referred to in Paragraph 1 herein shall be liable to contributions payment and the payment of compulsory insurance contributions in line with the monthly basis that is used to calculate contributions and that is prescribed and announced by the Minister. The amount of the monthly basis that is used for the calculation of contributions shall be determined against the salary that the crew member would receive for the same or similar jobs aboard a ship in national navigation.

(9) The liability and the type of contributions, as well as monthly sums of contributions to be paid shall be established by a decision of the Tax Administration .... shall be subject to regulations governing contributions for compulsory insurance schemes, as well as general tax regulations.

These amendments of the Maritime Code were primarily characterized by the modifications of the tax system, i.e. the 
application of such modifications to seafarers. The fact that it is clearly stipulated that compulsory insurance scheme payments (both health and pension) are a tax deductible expense is of relevance. It is also important that there is a clear provision that "A crew member in international navigation, regardless of the ship's nationality, shall be an insured person with a compulsory pension scheme in the Republic of Croatia if he or she has a permanent residence or a temporary residence (resident) in the Republic of Croatia and a compulsory medical insurance, as well as occupational safety and health insurance if he or she has a permanent residence or an approved permanent sojourn in the Republic of Croatia, unless otherwise regulated by an interstate social insurance contract." (Maritime Code, 2007), as well as that apart from the clarity of this provision, it is also relevant that it took into consideration the fact that in practice it is often foreigners and not only the citizens of the Republic of Croatia who benefit from compulsory insurance schemes, and that they should therefore be liable to make payments if they have any of the legally proscribed relations with the Republic of Croatia.

\section{AMENDMENTS OF THE MARITIME CODE, OG 146/08}

\section{Article 18}

In Article 129, paragraph 2 is amended to read:

"(2) The registration of the compulsory pension scheme and the compulsory health insurance of the crew member referred to in paragraph 1 herein, whose employer, ship operator or company is a domestic legal person, shall be made by the employer, ship operator or the company."

In paragraph 3, the words "ship operator or the company" shall be added after the words "employer".

These amendments merely additionally define who makes the registration by adding the words ship operator or the company to term employer. In comparison with some other modifications, this is one that could have been avoided, i.e. this extension could easily have been achieved by the interpretation process. Possible damage is that if so many details were provided in this respect, in other cases the very interpretation, i.e. extension of application by way of interpretation can me aggravated by the observation that "had the legislator wanted it, he would certainly have changed it when he was so careful to enter this change by additionally listing ship operator and the company with the employer in Article 129, Paragraph 2 of the Maritime Code."

\section{AMENDMENTS OF THE MARITIME CODE, OG 61/11}

\section{Article 11}

In Article 125, paragraph 4 is added after paragraph 3 to read:

"(4) Working, living and social conditions of seafarers shall be governed by collective contract."
Article 12

In Article 126, paragraph 2, word "liner" is added after word "international".

\section{Article 13}

In Article 128, paragraph 2 is amended to read:

"(2) For the achievement of the required 183 days from paragraph 1 of this Article for the year for which the income tax obligation is established, days spent on board, days spent travelling from place of residence to place of embarkation, days required for return trip, days of treatment of illnesses or injuries occurring on the way to the ship, on board or on return and days spent at professional training abroad shall be included."

After paragraph 2, new paragraph 3 is added which reads:

"(3) Days from paragraph 2 of this Article may include days spent on board, days spent travelling from place of residence to place of embarkation, days required for return trip, days of treatment of illnesses or injuries occurring on the way to the ship, on board or on return and days spent at professional training abroad, which were not calculated into the 183 days in the preceding year.

\section{Article 14}

After Article 129, Article 129 (a) is added which reads: "Article 129 (a)

(1) To a crew member, regardless of the nationality and type of ship and in what capacity he/she embarked on the ship, every 12 months spent on board as member of crew of ship in international and national navigation shall be counted as 15 months of pensionable service.

(2) The age limit for the obtainment of right to retirement of insured person - crew member pursuant to the Pension Insurance Act shall be 60 years of age, provided he/she has a minimum 15 years of pensionable service as crew member of ship in international and national navigation.

(3) A crew member of a ship in international navigation shall be obligated to pay additional contribution and contribution for insurance with increased duration based on the monthly basis for the calculation of contributions for compulsory insurance schemes proscribed and published by the minister, as follows: - additional pension insurance contribution for insurance with increased duration,

- additional pension insurance contribution based on individual capitalized savings for insurance with increased duration (for persons covered by such insurance).

(4) The rate of additional contribution for insurance with increased duration from paragraph 1 of this Article for crew member from paragraph 3 herein shall be calculated in keeping with the applicable rate of increase of pensionable service by the application of the general act governing contributions.

(5) The additional contribution for insurance with increased 
duration for crew member from paragraph 3 herein shall be calculated and charged by the Tax Authority in the manner proscribed by Article 129, paragraph 9 of this Act.

(6) The insurance with increased duration for crew member from paragraph 3 of this Article shall be calculated during the procedure of realization of his/her retirement right based on the certificate of the Tax Authority that additional contribution for insurance with increased duration was paid in full.

(7) For crew member of ship in international navigation, the employer shall pay additional contribution and be subject to the calculation and payment of the contribution for insurance with increased duration, in accordance with the general act governing contributions, as follows:

- additional pension insurance contribution for insurance with increased duration,

- additional pension insurance contribution based on individual capitalized savings for insurance with increased duration (for persons covered by such insurance).

(8) The provisions of the general act governing contributions and general act governing pension insurance shall be applied in the appropriate manner to any issues not covered by this Act, relating to insurance with increased duration of crew members."

\section{Article 69}

Article 4, paragraph 2, section $X V$, indent 2: Workplaces in sea transport, Act on Insurance with Increased Duration (Official Gazette no. 71/99,46/07 and 41/08) shall cease to apply on the date of entry into force of this Act.

These are currently the most relevant amendments of the Maritime Code for seafarers for more than one reason. First, they are a part of the Croatian positive legislation and since they entered into force, until another change, all actions of seafarers must be governed by them. Second, they nullified the dual position of seafarers brought about by the illegal actions of the executive authorities, without the participation of the legislator. The third is something negative. Namely, having finally resolved the issue of the so called accelerated years of pensionable service (by the latest amendments of the Maritime Code), a new issue arose. The seafarers are now denied the pension bonus which has been an integral part of their pension since January 1, 2012, because they realized their pension rights under more favourable conditions or in a more favourable way in keeping with special regulations, in this case the Maritime Code - had someone anticipated this issue, it could have been prevented by a simple addition of text into the Maritime Code. Unfortunately, this was not done and it is now clear that we are facing a new (and probably long) fight, this time with the Bonus Act. The common ground for this and the earlier issue is that in both cases we have an interpretation unfavourable to the seafarers, an interpretation that is almost impossible to arrive at by target or teleological interpretation.

\section{AN OVERVIEW OF (SOME) KEY ISSUES}

In our opinion, the key problem of seafarers in general, including when health and pension insurance are concerned, are the actions of the government in the widest sense of that term (including everyone from the legislator to the lowest clerk in the often long administrative and bureaucratic chain), which are in many situations contrary to the principles of legal safety and the rule of law. Probably the best example of this practice are the so called accelerated years of pensionable service for seafarers which were never abolished, at least not in the only way that acts can be put out of force ${ }^{(4)}$ - the same way the legal provision was adopted. Although the seafarers have never been formally divested of this right, in practice thousands of seafarers are deprived on a daily basis. Although this issue has been resolved pro futuro, the preceding period is plagued by a factual state that could serve as a basis for thousands of civil suits against the Republic of Croatia, either for the recovery of the overpaid amounts, or because a certain number of years will not be counted as the accelerated years of pensionable service. The pension bonus is currently a burning issue (by no means a negligible percentage, up to as much as 27\%), as is the question of the age of retirement which could more than logically be resolved by lowering their age limit in comparison with the general age limit proportionate to the so called accelerated years of pensionable service ( 12 years counted as 15).

\section{PROPOSALS DE LEGE FERENDA}

As stated earlier, significant modifications of the legal framework for any issue, including the problems of seafarers, can be achieved by means of the interpretation process. However, if the criteria of legal safety, rule of law and speed (if the legislator is fast $^{(5)}$ ) are applied, the legislator is definitely the first choice. What we primarily have in mind is a clear and unambiguous legal text, either a new act or amendment of an extant one, including the possible application of the constitutional option of lending certain parts a retroactive effect. Apart from this type of activity of the legislator, there is also the possibility of the so called credible interpretation, in which case there is an aggravating circumstance that such interpretation always has a retroactive

4 Also exception in the case of annulment by the Constitutional Court of the Republic of Croatia.

5 In essence the issue of possible speed is not contentious, since most of the acts are adopted by emergency procedure - the real issue is how to convince the decision makers that the problem actually exists and how to resolve it in the best possible way. 
effect, which is in principle considered bad for legal safety and rule of law.

Although this is by no means a closed list of proposals, considering the topic of this paper, we would primarily suggest that the legislator amend the Maritime Code with a provision that the current solution for the issue of accelerated years of pensionable service for all seafarers be lent a retroactive effect, and that the limitations from the Bonus Act not be applicable to seafarers. It would be useful, since the term seafarer is used in legal and sublegal acts ${ }^{(6)}$, to introduce the legal definition of the seafarer, clearly distinguishing this term from the concept of the crew member.

\section{CONCLUSION}

Understanding all the imputations and attempts to make a difficult situation even worse when it comes to seafarers and their rights is difficult to comprehend. We could list the arguments in favorem of the seafarers and their rights indefinitely, one was already provided in this paper, but we feel that there is no better argument than the fact that both in Croatia and abroad there is a saying that the seafarers have a bread with seven crusts. If we apply this saying to the rules of interpretation, primarily target or teleological one, it seems that all the issues we have been dealing with in this paper, as well as numerous others, have root in someone's arbitrary will, without any foundation in the Constitution and law. If that was really the case, now is the time to make some changes and do everything to restore to the seafarers, who are not merely one of the small number of globally recognized and acknowledged Croatian brands (apart from e.g. sport and tourism), but deserve wholehearted support ${ }^{(7)}$, their well-deserved status and rights. In so doing, in the long run, we should not fear the admission of illegal actions from the past and the rightful compensation of seafarers for the damage inflicted on them for years.

6 The Croatian legislator frequently uses the term seafarer, although sometimes (without any clear criterion) alternating the terms "seafarer" and 2crew member". This practice is also discernible in some sublegal acts, so that the term "seafarer" is used in their very titles, like e.g. the Ordinance on vocations and certificates of competencies for seafarers (OG 50/07, 62/09, 73/09, 15/10, 142/10, 64/11), Ordinance on Seafarer's Books and Embarkation Permits, Procedures and Mode of Registration and Deregistration of Seafarers in the Compulsory Pension Insurance Scheme and the Compulsory Health Insurance Scheme (OG 3/08), Ordinance on Mediation in Employment of Seafarers (OG 120/07).

7 If they sail with foreign companies, this can be considered a kind of an export if on Croatian ships, their expertise contributes to the safety of passenger and freight transportation, which is obviously a critical issue in the world today (let us remember the recent accident of the Costa Concordia cruiser), what would happen to our islands without seafarers, what to our shipyards ...

\section{REFERENCES}

Act on Insurance with Increased Duration, (1999), Narodne novine, 1999(71). Act on Insurance with Increased Duration, (2007), Narodne novine, 2007(46). Act on Insurance with Increased Duration, (2008), Narodne novine, 2008(41). Act on the Addition to Pensions Realised under the Pension Insurance Act, Official Gazette, (2007)79.

Act on the Addition to Pensions Realised under the Pension Insurance Act, Official Gazette, (2011)114.

Constitution of the Republic of Croatia, (1990), Narodne novine, (1990)56.

Constitution of the Republic of Croatia, (1997), Narodne novine, 1997(135).

Constitution of the Republic of Croatia, (1998), Narodne novine, 1998(8).

Constitution of the Republic of Croatia, (2000), Narodne novine, 2000(113).

Constitution of the Republic of Croatia, (2000a), Narodne novine, 2000(124).

Constitution of the Republic of Croatia, (2001), Narodne novine, 2001(28).

Constitution of the Republic of Croatia, (2001a), Narodne novine, 2001(41).

Constitution of the Republic of Croatia, (2001b), Narodne novine, 2001(55).

Constitution of the Republic of Croatia, (2010), Narodne novine, 2010(76).

Kačer, H., (2011), Odnos prethodnog i naknadnog vlasništva -fiducija, Aktualnosti hrvatskog zakonodavstva i pravne prakse, 18, pp. 65.- 71.

Labour Act, (2009), Narodne novine, 2009(149).

Labour Act, (2011), Narodne novine, 2011(116).

Mandatory Health Insurance Act, (2008), Official Gazette 2008(150).

Maritime code, (2007), Narodne novine, 2007(76).

Maritime code, (2004), Narodne novine, 2004(181).

Maritime code, (2007), Narodne novine, 2007(76)

Maritime code, (2008), Narodne novine, 2008(146).

Maritime code, (2011), Narodne novine, 2011(61).

Maritime Labour Convention ILO 186, available at: http://www.sph.hr/docs/sphHR/ documents/55/Original.pdf, [accessed 01.05. 2012.].

Pension Insurance Act, (1998), Narodne novine, 1998(102).

Pension Insurance Act, (2000), Narodne novine, 2000(127).

Pension Insurance Act, (2001), Narodne novine, 2001(59).

Pension Insurance Act, (2001a), Narodne novine, 2001(109).

Pension Insurance Act, (2002), Narodne novine, 2002(147).

Pension Insurance Act, (2003), Narodne novine, 2003(117)

Pension Insurance Act, (2004), Narodne novine, 2004(30).

Pension Insurance Act, (2004a), Narodne novine, 2004(177).

Pension Insurance Act, (2005), Narodne novine, 2005(92).

Pension Insurance Act, (2007), Narodne novine, 2007(43).

Pension Insurance Act, (2007a), Narodne novine, 2007(79).

Pension Insurance Act, (2008), Narodne novine, 2008(35).

Pension Insurance Act, (2010), Narodne novine, 2010(40).

Pension Insurance Act, (2010a), Narodne novine,2010(121).

Pension Insurance Act, (2010b), Narodne novine, 2010(130).

Pension Insurance Act, (2011), Narodne novine, 2011(61).

Pension Insurance Act, (2011a), Narodne novine, 2011(114).

Primorac, Ž., (2008), Liability of the Ship Owner for Death and Physical Injuries of Seafarers, magisterial thesis, Split: Faculty of Law.

Šimac, S., (1999), In rem Courts Jurisdiction from Article 161, paragraph 4 of the Maritime Code, Collection of Papers of the Split Faculty of Law, 36(55-56), pp. 612. 615

Visković, N., (2001), Teorija države i prava, Zagreb: Birotehnika. 